\title{
Distribution of the raccoon dog Nyctereutes procyonoides in western Poland
}

\author{
Natalia OsTen-SACken, Joanna ZIOMEK, Paweł KARdynia and Ewa ZGrabczyŃska \\ Department of Systematic Zoology, Faculty of Biology, Adam Mickiewicz University, Umultowska 89, \\ 61-614Poznań,Poland; e-mail: natalia.osten@onet.eu
}

\begin{abstract}
The raccoon dog Nyctereutes procyonoides (Gray, 1839) is an introduced canine species, currently widely distributed in Europe. The raccoon dog is a relatively new alien predator in Polish fauna and can be considered a threat to the native species. However, little is known about its distribution or habitat selection in western Poland. Until the 1970 s, only 20 single records of raccoon dogs in the western and south-western parts of Poland had been noted. New data on the numbers of raccoon dogs, its distribution and habitat preferences in the western Poland have been collected using questionnaires. 289 new localities have been reported. Raccoon dogs have been observed mostly in five types of habitats: forests, arable fields, banks of water bodies, roads and human settlements, wet meadows and marshes.
\end{abstract}

Key words: raccoon dog, alien species, habitat selection, distribution, western Poland

\section{INTRODUCTION}

The raccoon dog Nyctereutes procyonides (Gray, 1839) originates from the Far East and was introduced to Europe in the first half of the 20th century (Lavrov 1971). The numbers of individuals have increased rapidly and today it is widely distributed throughout Europe (Kauhala 1996a). In Finland its population peaked in the mid-1980s and since then it has been regulated (Kauhala \& Helle 1993, 1995). In Germany it expanded its range in the early 1960s (Drygala et al. 2001). The first information about the raccoon dog in Poland was obtained in 1955 from Bialowieża Forest (Andrzejewski \& Pielowski 2003, Kowalczyk et al. 2002). Intense studies on the distribution of the raccoon dog in Poland had been conducted until the 1970's and the data which are now available come largely from that period (Pucek \& Raczyński 1983). In 1999, the database of species introduced into Poland was developed for the Ministry of the Environment at the Institute of Nature Conservation, Polish Academy of Sciences in Krakow. This database shows that since 1970s the raccoon dog has spread across the country. The Institute of Nature Conservation has based its data on the studies from the 1970s and on information gained from foresters and hunters. However, the database does not provide detailed information about raccoon dogs' localities.

The raccoon dog has been an object of only a few ecological studies so far. Conducted studies were restricted to the north-eastern, eastern and central part of Poland (Wlodek \& Krzywiński 1986, Jędrzejewski \& Jędrzejewska 1993, Goszczyński \& Skoczyńska 1996, Goszczyński 1999, Kowalczyk et al. 2002). In some parts of Poland the density of the population is higher than the density of native predators such as the fox and the badger (Wlodek \& Krzywiński 1986). It is probably due to the high reproductive rate and omnivorous diet (Kauhala et al. 1993). The mean spring density of raccoon dogs was estimated at 0.37 individuals per square $\mathrm{km}$ in north-eastern Poland (Goszczyński 1999).

The racoon dog is a relatively new predator in the Polish fauna, and can be considered a threat to the native species. However, little is known about its density, colonisation, ecological 
parameters of population and possible interactions between them and other predators in western Poland.

The goal of our preliminary research was to estimate the distribution of raccoon dogs in western Poland. The data obtained will be used to update the "Atlas of Polish mammals".

\section{STUDY AREA}

The study was conducted in western and south-western Poland which includes three provinces: lubuskie, wielkopolskie and dolnośląskie (Fig. 2). This region covers the Wielkopolska part and the Silesian part of the Mid-Polish Lowlands situated in the drainage basin of the Oder River. That region includes the Toruńsko-Eberswaldzka Ice Marginal Channel, the Lubuskie Lake District, the Wielkopolska Lake District, Zielona Góra Height, the Leszczyńskie Lake District, the southern Wielkopolska Lowland, the Milicz-Glogów Depression, the Wal Trzebnicki, the Silesian Lowland and the Sasko-Eużyckie Lowlands (Kondracki 1998) (Fig. 1).

This region is characterised by high diversity of geomorphologic structures (from lowlands to uplands). The water bodies are abundant in these areas: a number of rivers (including the Oder River - the largest one) and lakes. Climate conditions in that part are moderated by oceanic influences (Kondracki 1998).

The northern part of the investigated region involves the Toruńsko-Eberswaldzka Ice Marginal Channel. The western part of the ice marginal channel is covered with meadows up to $12 \mathrm{~km}$ wide and vast forests complexes (Noteć River Forest). The Lubuskie Lake District comprises forest complexes with stands of oaks and numerous postglacial channel lakes. The Wielkopolska Lake District is characterised by water shortage as a consequence of low precipitation $(450-500 \mathrm{~mm})$. Tree stands in the region lack in oaks, and vegetation include variety of steppe elements. Landscape of the lake district represents big participation of arable fields and lakes. The Zielona Gora Height is a region covered mostly with forests, the lie of the land is relatively diversified and it includes a small number of lakes. The western and central part of the Leszczyńskie Lake District is characterised by numerous lakes and forests, whereas the northern and eastern part lacks in lakes and is dominated by arable fields. The southern Wielkopolska Lowland is a region divided by numerous river valleys with a mosaic of flat uplands lacking in lakes and basins. This area represents a low level of biodiversity. The uplands are substantially deforested and serve mostly as arable areas. In some placed there are patches of riparian forest, oak-lime-hornbeam forest or pine-spruce forest with admixture of oaks or in higher places with beeches, firs and mountain elements in the undergrowth. The Milicz-Głogów Depression includes two basins drained by the Barycz River. Forests in that region establish bigger complexes. The complexes comprise of pine forest, pine-spruce forest and riparian forest. In the vicinity of Żmigród and Milicz a complex of fish ponds is situated. The Wat Trzebnicki region is a strip of hills with its significant part covered with forest comprised of tree species typical of upland forests. Those are beech forests with spruce and fir, moreover pine-spruce forest are also present. The Silesian Lowland is a vast plain, divided by the Oder River with its tributaries. It is mostly an arable land with a few bigger forest complexes on sandy stream terraces. The Sasko-Łużyckie Lowlands include the middle parts of the drainage basin of the Nysa Eużycka River, the Bóbr River and the Kaczawa River. A part of that region is covered with the Lower Silesia Forest coniferous forests, in which the dominant species is the pine, with scattered admixture of deciduous trees (oaks, birches and beeches) and other coniferous trees species as the fir and the spruce. There are also arable fields, meadows and pastures in places lacking in forest (Kondracki 1998) (Fig. 1). 


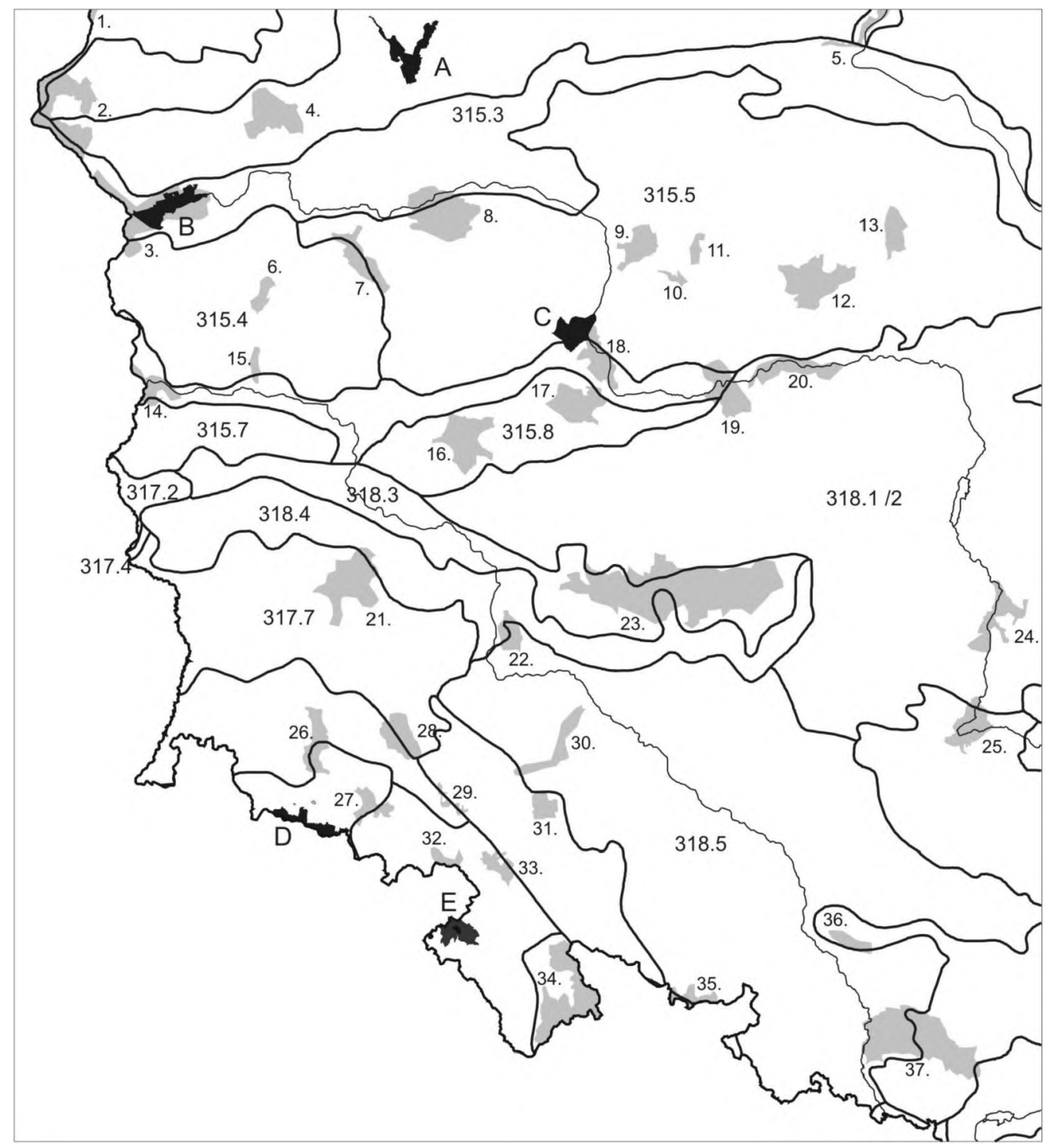

Fig. 1. Geographical characteristics of the research area including protected areas within. Mezoregions: 315.3 Toruńsko-Eberswaldzka Ice Marginal Channel, 315.4 Lubuskie Lake District, 315.5 Wielkopolska Lake District , 315.7 Zielona Góra Height, 315.8 Leszczyńskie Lake District, 318.1/2 southern Wielkopolska Lowland, 318.3 MiliczGlogów Depression 318.4 Wal Trzebnicki, 318.5 Silesian Lowland, 317.2, 317.4, 317.7 Sasko-Lużyckie Lowland; National Parks (NP): A. Drawa NP. B. Ujście Warty NP, C. Wielkopolska NP, D. Karkonosze Mountains NP, E. Stolowe Mountains NP.; Landscape Parks (LP): 1. Lower Oder Valley LP, 2. Cedynia LP, 3. Ujście Warty LP, 4. Barlinek-Gorzów LP, 5. Vistula LP, 6. Lagów LP, 7. Pszczew LP, 8. Sieraków LP, 9. Zielonka Forest, 10. Promno LP, 11. Lednica LP, 12. Powidz LP, 13. Gopło LP, 14. Krzesin LP, 15. Gryżyna LP, 16. Przemęt LP, 17. D. Chlapowski LP, 18. Rogalin LP, 19. Żerków-Czeszewo LP, 20. Warta LP, 21. Przemków LP, 22. Jezierzyca Valley LP, 23. Barycz Valley LP, 24. Warta-Widawka LP, 25. Zalęcze LP, 26. Bóbr Valley LP. 27. Rudawy LP 28. Chełmy LP. 29. Książ LP, 30. Bystrzyca Valley LP, 31. Ślęża LP, 32. Sudety Walbrzyskie LP, 33. Owl Mountains LP, 34. Śnieżnik LP, 35. Opawskie Mountains LP, 36. Śvięta Anna Mountain LP, 37. Rudy LP. 


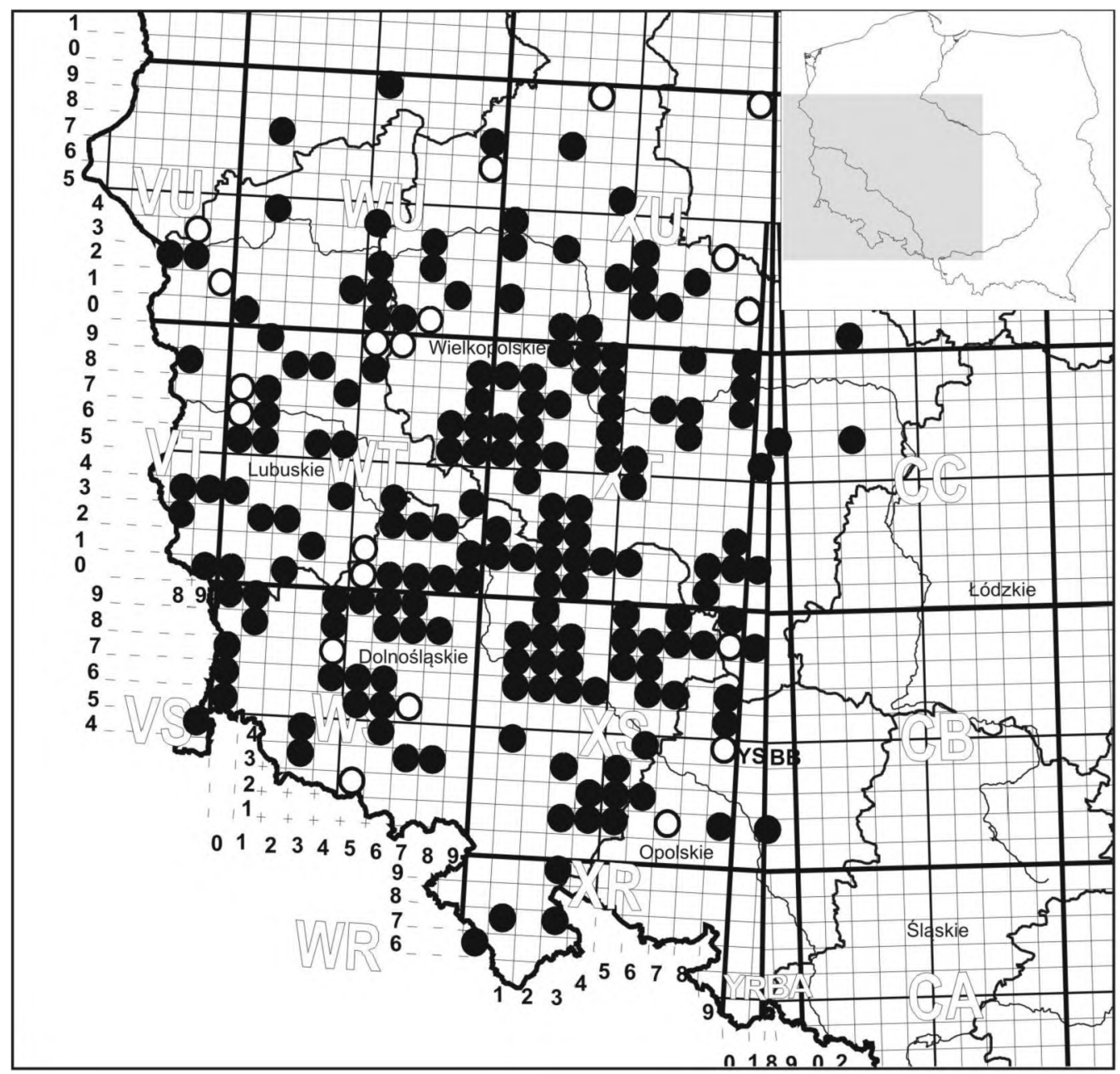

Fig. 2. Localities of the raccoon dog in western Poland: empty circles - localities known in 70 s, black circles - new localities.

\section{METHODS}

In 2004. 187 questionnaires were sent to forestry offices. national parks. landscape parks and hunting clubs in western Poland to evaluate the present and historical presence of raccoon dogs in that region.

The questionnaires comprised of two parts: the first was an information leaflet and the second a set of questions. The one page information leaflet included a picture of the raccoon dog and information on the its appearance, tracks, biology and a short history of its presence in Poland. Moreover, it provided guidelines on how to distinguish the raccoon dog from the raccoon Procyon lotor (Linnaeus. 1758) and a picture of the raccoon. The question part included following queries:

1. Have you ever seen a raccoon dog in the wild? Please state the time and the place, if possible. 
2. In what kind of habitat did you observed the animal? (forest, water bodies, arable fields, human settlements, if other environments - what kind?)

3. Have you ever seen a dead raccoon dog/roadkill? Please state the time and the place, if possible.

4. If possible, provide any other information concerning the raccoon dog not mentioned above.

Until 2005, we had received 187 answers. The questionnaires were filled by professional staff of the national parks, landscape parks, forest management and hunters, therefore the information was assumed objective and all observation credible. The obtain data were often documented with photos, mainly of death animals or roadkills. The localities in the wielkopolskie voivodship were verified by field inspections $(n=15)$. During inspections a search for racoon dogs' burrows, tracks and latrines was carried out.

The records were mapped using the UTM grid of $10 \times 10$ kilometres (Fig. 2). One square contains a single point which can cover a few localities, hence the number of points on the map does not coincide with the number of localities given in the text.

\section{RESULTS}

We have obtained data on 289 new localities of the raccoon dog in the study area (Fig. 2). The earliest records referring to raccoon dogs presence in that region come from 1978.

The collected data indicate that the particularly intensive expansion of the raccoon dog has been observed since 1990s: the individuals have settled in new areas and their number has increased in all the localities. For example, in the Sieraków Forest District (30413 ha) (Fig. 1): in $2001-117$ individuals were recorded, in 2002 - 153 individuals, in 2003 - 175 individuals, and in $2004-231$ individuals.

The information about the raccoon dog presence came also from many protected areas: Wielkopolska National Park, Drawa National Park, Ujście Warty National Park, BarlinekGorzów Landscape Park, Lower Silesia Complex of Landscape Parks, General Dezydery Chlapowski Landscape Park, Lednica Landscape Park, Lagów Landscape Park, Warta Landscape Park, Promno Landscape Park, Pszczew Landscape Park, Ujście Warty Landscape Park, Zielonka Forest Landscape Park (Fig. 1). Raccoon dogs were also observed in the foothills and mountains in south - west Poland (Fig. $1 \& 2$ ).

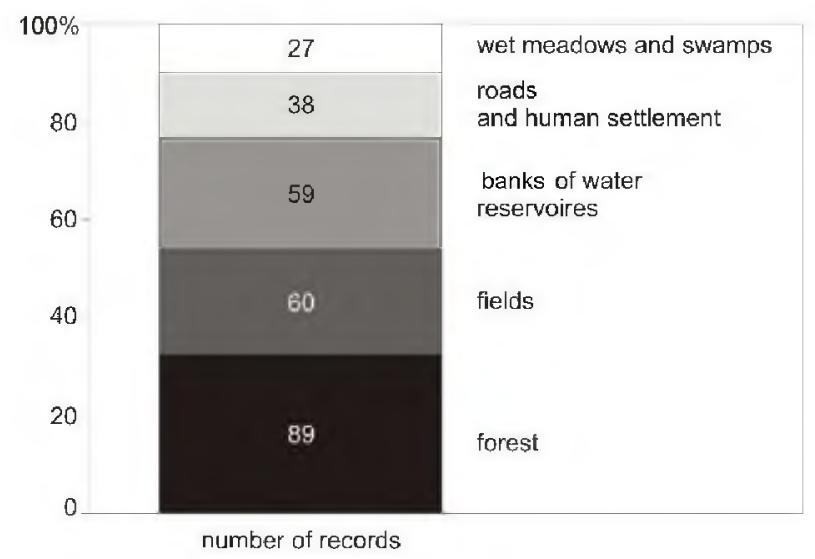

Fig. 3. Habitat selection of raccoon dogs in western Poland according to records from questionnaires and direct observations $(n=273)$. 
Habitat selection of the raccoon dogs is presented on Fig. 3. Animals preferred forest habitats, but they foraged also in fields. The least frequently occupied habitats were meadows and areas around human settlement. Some reports described incidents with tourists at camping sites, where raccoon dogs ate leftovers, or explored dumps. Respondents reported often paired animals feeding together, but without information about their sex.

Nine percentage of questionnaires reported that animals fed on eggs and nestlings of waterfowl (ducks, wild geese), fish, frogs, snails, heads of maize, seeds of cereals, food offered by forest officers for wild boars and other animals.

In 43 questionnaires ( $23 \%$ of all questionnaires) contained information on dead individuals found by the roads. The estimated number of raccoon dogs killed in road accidents was 150 . For example 54 road-kills were found on the road Kostrzyn - Słonsk (approximately $15 \mathrm{~km}$ ) within only two years (2001-2002).

\section{DISCUSSION}

Until the 1970 the raccoon dog had been distributed most numerously in the Pomarania Lake District, the Masuria Lake District, the Mazovia Lowland, the Podlasie region, the Małopolska Uphill, the Lublin Uphill and the Sandomierz Basin. In the other parts of the country the raccoon dog had been scarce, moreover in the Wielkopolska Lowland and the Silesian Lowland had been virtually not recorded (Pucek \& Raczyński 1983). Until 1970 only 20 localities of the raccoon dog had been known in western part of Poland. The questionnaires from 2004-2005 revealed 289 new localities of that species in western Poland. Since there had not been any research conducted on the raccoon dog from that area before 2004-2005, there is no data to compare with in terms of the origin and the pace of the expansion in that area. According to the questionnaires the raccoon dog started its expansion in the Wielkopolska region in the second half of the 1970 s. The first reports on its occurrence come from Krzywin (UTM: XT 25) from 1978-1979. Moreover, the obtained data imply that in the same year raccoon dogs were present in Pszczew Landscape Park situated in the Lubuski Lake District and the Poznan Lake District. Until 1990 there had not been probably any data about its presence in the Lower Silesia region. The first records about its occurrence in the Lower Silesia come from 1990 from place called Modła (UTM: WS 58). Since 1990 the number of encounters with raccoon dogs has increased in the whole study area.

The information about road kills from western Poland is the first data on the road mortality of raccoon dogs in that region. Data on road kills can be helpful in determining the abundance of population and its density tendencies. It is confirmed by data from Japan where along with the density increase the number of road kills rose (Seaki \& Macdonald 2004). The obtained data on raccoon dogs distribution and number of road kills implicate a rising tendency in the predator abundance in western Poland.

The raccoon dog can settle in a wide spectrum of habitats. Its habitat niche is broader than the niche of the red fox (Baltrunaite 2003) and it has the capacity to use various kinds of shelters (Volokh \& Rozhenko 2004). In southern Ukraine it occurs most frequently in river floodplains, on marine islands and spits (Volokh \& Rozhenko 2004). In morainic uplands in Lithuania the raccoon dog uses forest habitats intensively. It is significantly more frequent in coniferous, hard/mixed broad-leaved, and mixed spruce - hard/mixed broad - leaved stands (Baltrunaite 2003). In southern Finland during early summer it favours shores of lakes with dense undergrowth providing food and shelter, whereas during autumn it prefers moist heaths with abundant berries (Kauhala 1996c).

The questionnaire findings show that in western Poland raccoon dogs prefer forest areas. These data are in accordance with results from eastern Poland (Białowieża Primeval Forest), 
where the river valleys, wet alder woods, elm-ash forests and oak-linden-hornbeam forests are the preferred habitats during the whole year (Jędrzejewska \& Jędrzejewski 1998). The reports from western Poland describe visits of raccoon dogs to arable fields and to dumps. In Finland the animals also appear near human settlements visiting compost heaps and forage in arable fields (Kauhala 1996b). The data from western Poland indicate that raccoon dogs can be locally harmful to waterfowl colonies, where they eat many eggs and nestlings, and frogs. Therefore, that data together with the observed increase of their density, may suggest an increasing influence on the local avifauna. Nevertheless, still only a few research on the predation and competition of the raccoon dog with the native fauna in Europe has been conducted (Kauhala 1996a) and more scientific investigation is needed.

\section{ACKNOWLEDGMENTS}

The authors wish to express their gratitude to many persons in the forestry offices, national parks, landscape parks and hunting clubs in western Poland who were very kind to provide information about the raccoon dog.

\section{REFERENCES}

ANDRZEJEWSKI R. \& PIELOWSKI 2003. Gospodarka łowiecka a różnorodność biologiczna [Hunting management and biodiversity]. In: R. ANDRZEJEWSKI \& A. WEIGLE (eds), Różnorodność biologiczna Polski [Biodiversity in Poland]: 217-223. Narodowa Fundacja Ochrony Środowiska, Warszawa, 284 pp.

BALTRUNAITE L. 2003. Feeding habits and habitat use of red fox (Vulpes vulpes) and raccoon dog (Nyctereutes procyonoides) in Morainic Uplands, Lithuania. In: Abstracts of the 4th European Congress of Mammalogy, Bmo, Czech Republic, 27th July-1st August 2003, pp. 58. Institut of Vertebrate Biology, Academy of Sciences of the Czech Republik, Bmo.

Drygala F., MIX H. M., STIER N., \& ROTH M. 2001. Preliminary findings from ecological studies of the raccoon dog (Nyctereutes procyonoides) in eastern Germany. Zeitschrift für Ökologie und Naturschutz 9 (3): 147-152.

GoSZCZYNSKI J. 1999. Fox, raccoon dog and badger densities in North Eastern Poland. Acta Theriologica 44: 413-420.

GOSZCZYNSSKI J. \& SKOCZYNSKA J. 1996. Density estimation, family group size and recruitment in a badger population near Rogów (Central Poland). Miscellania Zoològica 19 (2): 27-33.

JĘDRZEJEWSKA B. \& JĘDRZEJEWSKI W. 1998. Predation in Vertebrate Communities: the Bialowieża Forest as a Case Study. Springer Verlag, Berlin-Heidelberg, $450 \mathrm{pp}$.

JEDRZEJEWSKI W. \& JEDRZEJEWSKA B. 1993. Predation on rodents in Białowieża Primeval Forest, Poland. Ecography 16: 47-64.

KAUHALA K. 1996a. Reproductive strategies of the raccoon dog and the red fox in Finland. Acta Theriologica 4: 51-58.

KAUHALA K 1996b. Introduced carnivores in Europe with special reference to central and northern Europe. Wildlife Biology 2: 197-204.

KaUHALA K. 1996c. Habitat use of raccoon dogs, Nyctereutes procyonides, in southern Finland. Zeitschrift für Säugetierkunde 61: 269-275.

KAUHALA K. \& HELLE E. 1993. Factors affecting the numbers of raccoon dog populations in Finland. Suomen Riista 39: $102-110$.

KaUHALA K. \& HeLlE E. 1995. Population ecology of the raccoon dog in southern Finland - a synthesis. Wildlife Biology 1: 3-9.

KaUHala K., Kaunisto M. \& Helle E. 1993. Diet of the raccoon dog, Nyctereutes procyonoides, in Finland. Zeitschrift für Saugetierkunde 58: 129-136.

KONDRACKI J. 1998. Geografia regionalna Polski [The regional geography of Poland]. Polskie Wydawnictwo Naukowe, Warszawa, 460 pp. [In Polish]

KOWALCZYK R., ZALEWSKI A., JĘDRZEJEWSKA B. \& JEDRZEJEWSKI W. 2003. Social relationships in raccoon dogs. In: Abstracts of the 4th European Congress of Mammalogy, Bmo, Czech Republic, 27th July-1st August 2003, pp. 114. Institut of Vertebrate Biology, Academy of Sciences of the Czech Republik, Brno.

LAVROV N. P. 1971. [The results of reintroduction of the raccoon dog (Nyctereutesprocyonoides) in different provinces of the USSR]. Trudy Kafedry Biologii MGZPI 29: 101-160. [In Russian]

PUCEK Z. \& Raczyński J. (eds) 1983. Atlas of Polish Mammals. Polish Scientific Publishers. Warsaw, 188 pp. [In Polish]

SEAKI M. \& MACDONALD D. W. 2004. The effects of traffic on the raccoon dog (Nyctereutes procyomoides viverrimus) and other mammals in Japan. Biology Conservation 118: 559-571. 
VOLOKH A. M. \& ROZHENKo N. V. 2004. Biotopic distribution and shelters of the raccoon dog (Nyctereutes procyonoides) in southern Ukraine. Zoologicheskii Zhurnal 83: 635-638. [In Russian with English summary]

WLODEK K. \& KRZYWLiski A. 1986. Zu Biologie und Verhalten des Marderhunds (Nyctereutes procyonoides) in Polen. Zeitschrift für Jagdwissenschaft 32: 203-214.

\section{STRESZCZENIE}

\section{[Rozmieszczenie jenota Nyctereutes procyonoides w zachodniej Polsce]}

W latach 2004-2005 zebrano dane o występowaniu i preferencjach siedliskowych jenota Nyctereutes procyonoides (Gray, 1839) na obszarze zachodniej Polski. Informacje o wysteppowaniu jenota pochodzą przede wszystkim $\mathrm{z}$ danych uzyskanych $\mathrm{z}$ Parków Narodowych, Parków Krajobrazowych, Nadleśnictw i Klubów Łowieckich oraz z inspekcji terenowych. Do lat siedemdziesiatych dwudziestego wieku jenot znany byl w zachodniej Polsce tylko z dwudziestu stanowisk. Aktualnie zebrano dane o 289 stanowiskach (Fig. 1). Jenot obserwowany byl w lasach, na polach uprawnych, na brzegach zbiorników wodnych, wilgotnych ląkach i bagnach oraz w pobliżu siedzib ludzkich (Fig. 2). 